\title{
A Study of Differences in Financial Performance under Indian GAAP and IFRS: Case of Noida Toll Bridge Company Limited
}

\author{
Arash Naderian and B. Mahadevappa* \\ Department of Studies in Commerce, University of Mysore Mysore, India
}

\begin{abstract}
The use of a single set of high quality accounting standards would facilitate investment and other economic decisions across borders, increase market efficiency, and reduce the cost of raising capital, in these aspects IFRS is the best set of accounting standards which have been adapted by 115 countries all over the world. In this article investigators considered the impact of convergence with IFRS on stamen of financial position of Nodia Toll Bridge Company Limited for the year2010, we considered the effect of transition to IFRS as well asratio of changes between each item by using of: Ratio $=\frac{x \mathbf{2}-x \mathbf{1}}{x \mathbf{1}} \times \mathbf{1 0 0}$ So after finding the ratio of changes we start to find the reason of these changes through the comparing between IFRS and Ind AS.
\end{abstract}

Keywords: IFRS, Indian GAAP, International Accounting

\section{Introduction}

The most effective way of achieving comparability is through adopting financial reporting frameworks based on International Financial Reporting Standards (IFRSs) issued by the International Accounting Standards Board (IASB) by any individual country (Ramanna \& Sletten, 2010). The adoption of IFRS relies on each individual country since the IASB, as a standard setting body, does not have the enforcement power. Furthermore even if a country decides to harmonize with IFRS, the compliance level is still dependent on that country's enforcement mechanisms, while there are still arguments about the need to achieve harmonization of international financial reporting (Sunder, 2009; Chua \& Taylor, 2008).

International Financial Reporting Standards (IFRS) convergence, in recent years, has gained momentum all over the world. As the capital markets become increasingly global in nature, India being one of the key global players, convergence to IFRS will enable Indian entities to have access to international capital markets without having to go through the cumbersome conversion and filing process. It will lower the cost of raising funds, reduce accountants' fees and enable faster access to all major capital markets. Furthermore, it will facilitate companies to set targets and milestones based on a global business environment, rather than an inward perspective.

\section{Need for the Study}

There are conceptual differences between Accounting Standards in India (AS) and the IFRS. Keeping in view the extent of gap between these two standards, convergence process would need careful handling. By introducing a new company law, the Indian Government has initiated the process to amend the legal and

*Email: mahadevappa@commerce.uni.mysore.ac.in 
regulatory framework. The convergence would involve impact assessment, revisiting accounting policies and thereafter changing the accounting \& operational systems in order to be fully compliant with IFRS.

\section{Objectives of Study}

The main objective of this study was to identify differences between Indian GAAP from the corresponding IFRS in case of Noida Toll Bridge Company Limited, by analysing the financial statements. The financial statement of Noida Toll Bridge Company Limited as at March 31, 2010 was considered in both IFRS and Indian GAAP. In other word the objectives of the study concentrate on:

- To analyse the financial statements of Nodia Toll Bridge Company Limited to examine the extent of differences between Indian GAAP and IFRS.

\section{Hypotheses}

In context of the background, this study seeks to examine the following hypotheses:

H1: There exists difference in measurement of income under Indian GAAP and IFRS.

H0: There exists no difference in measurement of income under Indian GAAP and IFRS.

\section{Methodology}

In this article, investigators used financial statement of Noida Toll Bridge Company Limited as at March 31, 2010 and compared this statements based on IFRS as well as Indian GAAP, to make out the differences and calculate the ratio of changes by using of the formula:

$$
\text { Ratio }=(x 2-x 1) / x 1 \times 100 .
$$

By using of above formula, investigators have considered the ratio of changes in the financial statements of Noida Toll Bridge Company Limited, taken directly from the company web site.

In this article investigators extract those items in the financial statement of Noida Toll Bridge Company Limited, which are affected by the application of IFRS and also discussions are made about the reason of such changes.
According to Table1 and Figure 1, we can absorb that there are differences between financial elements of Noida toll bridge company annual report under Indian GAAP and IFRS, hence there is differences on intangible asset, total non- current assets, total current assets, total assets, interest bearing loans and borrowings, provisions, deferred tax liability, total non-current liabilities, interest bearing loans and borrowings, provisions, total current liabilities, total liabilities, total assets less total liabilities, securities premium, effect of currency translation, retained earnings and total equity.

\section{Findings and Discussion}

Items which are affected while applying IFRS based on Table No1 considered one by one as following:

\subsection{According to IAS 38 and according to Accounting Standard (AS) 26 (Intangible Assets)}

Under Indian GAAP, Intangible Assets has been amortized using unit of usage method, since acquisition of such asset while in IFRS, change of amortization method from SLM to unit of usage method in the year ended March 31, 2009 has been considered as change in accounting estimates and hence has been applied from 2008-09 in accordance with IAS-8 "Accounting policies, Changes in Accounting Estimates and Errors". It is due to recognition of Intangible assets.

\subsubsection{IFRS}

Cost Model and Revaluation Model: An entity shall choose either the Cost Model or the Revaluation Model as its accounting policy. Revaluation model is permitted only where there is an active market for the underlying intangibles. An entity shall assess whether the useful life of an intangible asset is finite or indefinite. If finite, the length of/or number of production or similar units would constitute useful life. An intangible asset shall be regarded by the entity as having an indefinite useful life when, based on an analysis of all of the relevant factors, there is no foreseeable limit to the period over which the asset is expected to generate net cash inflows for the entity. 
Table 1. Noida Toll Bridge Company Limited and its subsidiary company reconciliation of equity at $31^{\text {st }}$ March 2010

\begin{tabular}{|c|c|c|c|c|}
\hline & INDIAN GAAP US(\$) & IFRS US (\$) & $\begin{array}{l}\text { Effect of transition to } \\
\text { IFRS US (\$) }\end{array}$ & Ratio of Changes \\
\hline Property, plant and equipment & $1,743,773$ & $1,743,773$ & - & \\
\hline Intangible asset & $127,958,502$ & $119,800,921$ & $(8,157,581)$ & -6.37 \\
\hline Employee Benefit & 103,247 & 103,247 & - & \\
\hline Trade receivable & 347,939 & 347,939 & & \\
\hline Loans \& Advances & 67,702 & 67,702 & & \\
\hline Total Non Current Assets & $130,221,163$ & $122,063,582$ & $(8,157,581)$ & -6.26 \\
\hline Inventories & 59,851 & 59,851 & - & \\
\hline Trade receivables & 994,501 & 994,501 & - & \\
\hline Loans and Advances & $4,317,011$ & $4,317,011$ & - & \\
\hline Prepayments & 62,846 & 62,846 & - & \\
\hline Available for sale investments & $4,965,712$ & $4,966,843$ & 1,131 & 0.02 \\
\hline Cash and Cash Equivalents & 815,773 & 815,773 & - & \\
\hline Total Current Assets & $11,215,694$ & $11,216,825$ & 1,131 & 0.01 \\
\hline Total Assets & $141,436,857$ & $133,280,407$ & $(8,156,450)$ & -5.76 \\
\hline Interest bearing loans and borrowings & $37,438,489$ & $36,386,090$ & $(1,052,399)$ & -2.81 \\
\hline Provisions & $2,121,381$ & $2,130,417$ & 9,036 & 0.42 \\
\hline Deferred Tax Liability & $1,704,621$ & $3,717,031$ & $2,012,410$ & 118 \\
\hline Total Non Current Liabilities & $41,264,491$ & $42,233,538$ & 969,047 & 2.34 \\
\hline Interest bearing loans and borrowings & - & $2,358,443$ & $2,358,443$ & 100 \\
\hline Trade and other payables & $2,950,115$ & $2,950,115$ & - & \\
\hline Provisions & $1,275,469$ & 620,687 & $(654,782)$ & -51.33 \\
\hline Provisions for taxes & $3,404,167$ & $3,404,167$ & - & \\
\hline Total Current Liabilities & $7,629,751$ & $9,333,412$ & - & 22.32 \\
\hline Total Liabilities & $48,894,242$ & $51,566,950$ & $2,672,708$ & 5.46 \\
\hline $\begin{array}{l}\text { Total Assets less Total } \\
\text { Liabilities }\end{array}$ & $92,542,615$ & $81,713,457$ & $(10,829,158)$ & -11.7 \\
\hline Issued capital & $42,419,007$ & $42,419,007$ & - & \\
\hline Securities premium & $32,039,889$ & $32,177,308$ & 137,419 & \\
\hline Debenture Redemption Reserve & 326,711 & 326,711 & - & \\
\hline $\begin{array}{l}\text { Net unrealised gains on available for sale } \\
\text { investment }\end{array}$ & - & 1,132 & 1,132 & \\
\hline General Reserves & - & 11,142 & 11,142 & \\
\hline Effect of currency Translation & $(1,170,667)$ & $(1,584,376)$ & $(413,709)$ & \\
\hline Retained Earnings(profit \& Loss A/C) & $18,927,675$ & $8,362,533$ & $(10,565,142)$ & \\
\hline Total Equity & $92,542,615$ & $81,713,457$ & $(10,829,158)$ & \\
\hline
\end{tabular}

Source of Data: Noida Toll Bridge Company Annual Report.

Date: July 20, 2010.

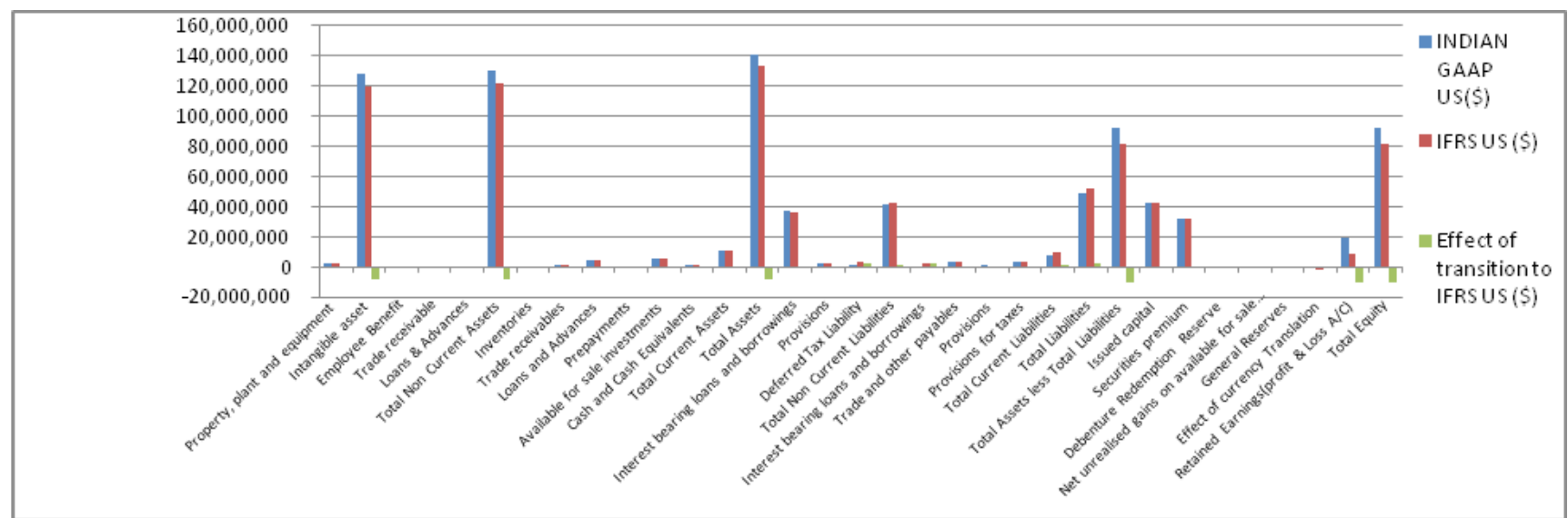

Figure 1. Noida toll bridge company annual report under Indian GAAP and IFRS. 


\subsubsection{Indian GAAP}

Cost Model only: After initial recognition, an intangible asset should be carried at its cost less than any accumulated amortization and any accumulated impairment losses. Revaluation of intangible assets is prohibited as well as revaluation is prohibited.

There is a rebuttable presumption that the useful life of an intangible asset will not exceed ten years from the date when the asset is available for use.

\subsubsection{Recognition and Measurement}

The recognition of an item as an intangible asset requires an entity to demonstrate that the item meets:

(a) The definition of an intangible asset

(b) The recognition criteria.

This requirement applies to costs incurred initially to acquire or internally generate an intangible asset and those incurred subsequently to add to or replace part of or service it.

An asset is identifiable if it either:

(a) is separable, i.e. capable of being separated or divided from the entity and sold, transferred, licensed, rented or exchanged, either individually or together with a related contract, identifiable asset or liability, regardless of whether the entity intends to do so, or,

(b) Arises from contractual or other legal rights, regardless of whether those rights are transferable or separable from the entity or from other rights and obligations.

An intangible asset shall be recognised if, and only if:

(a) it is probable that the expected future economic benefits that are attributable to the asset will flow to the entity, and

(b) the cost of the asset can be measured reliably.

The probability recognition criterion is always considered to be satisfied for intangible assets that are acquired separately or in a business combination.
An intangible asset shall be measured initially at cost. The cost of a separately acquired intangible asset comprises:

(a) its purchase price, including import duties and nonrefundable purchase taxes, after deducting trade discounts and rebates

(b) any directly attributable cost of preparing the asset for its intended use. In accordance with IFRS 3 Business Combinations, if an intangible asset is acquired in a business combination, the cost of that intangible asset is its fair value at the acquisition date. If an asset acquired in a business combination is separable or arises from contractual or other legal rights, sufficient information exists to measure reliably the fair value of the asset.

In accordance with this Standard and IFRS 3 (as revised in 2008), an acquirer recognizes at the acquisition date, separately from goodwill, an intangible asset of the acquiree, irrespective of whether the asset had been recognized by the acquiree before the business combination. This means that the acquirer recognizes as an asset separately from goodwill an in-process research and development project of the acquiree if the project meets the definition of an intangible asset.

\subsubsection{Measurement after Recognition}

An entity shall choose either the cost model or the revaluation model as its accounting policy. If an intangible asset is accounted for using the revaluation model, all the other assets in its class shall also be accounted for using the same model, unless there is no active market for those assets.

Cost model: After initial recognition, an intangible asset shall be carried at its cost less than any accumulated amortization and any accumulated impairment losses.

Revaluation model: After initial recognition, an intangible asset shall be carried at a revalued amount, being its fair value at the date of the revaluation less any subsequent accumulated amortization and any subsequent accumulated impairment losses. For the purpose of revaluations under this Standard, fair value 
shall be measured by reference to an active market. Revaluations shall be made with such regularity that at the end of the reporting period the carrying amount of the asset does not differ materially from its fair value.

An active market is a market in which all the following conditions exist:

(a) the items traded in the market are homogeneous

(b) willing buyers and sellers can normally be found at any time

(c) prices are available to the public

If an intangible asset's carrying amount is increased as a result of a revaluation, the increase shall be recognized in other comprehensive income and accumulated in equity under the heading of lunation surplus. However, the increase shall be recognized in profit or loss to the extent that it reverses a revaluation decrease of the same asset previously recognized in profit or loss. If an intangible asset's carrying amount is decreased as a result of a revaluation, the decrease shall be recoznised in profit or loss. However, the decrease shall be recognized in other comprehensive income to the extent of any credit balance in the revaluation surplus in respect of that asset.

\section{According to Accounting Standard (AS) 26}

An intangible asset should be recognized if, and only if

(a) it is probable that the future economic benefits that are attributable to the asset will flow to the enterprise

(b) the cost of the asset can be measured reliably.

An enterprise should assess the probability of future economic benefits using reasonable and supportable assumptions that represent best estimate of the set of economic conditions that will exist over the useful life of the asset.

An enterprise uses judgment to assess the degree of certainty attached to the flow of future economic benefits that are attributable to the use of the asset on the basis of the evidence available at the time of initial recognition, giving greater weight to external evidence, and an intangible asset should be measured initially at cost.

\subsection{IFRS 9 and AS 13 (Recognition and Measurement of Financial Instruments)}

Quoted investments measured at cost under Indian GAAP have been classified as Available-for-Sale financial assets under IAS 39, Financial Instruments Recognition and Measurement and remeasured at fair value. Changes in the fair value of these financial assets are recognized directly in equity through the statement of changes in equity. It is due to recognition of financial instruments.

Interest-bearing loans and borrowings have been restated to amortized costs using the effective interest rate method under IAS 39, Financial Instruments Recognition and Measurement, with the discount being accreted through the Profit and Loss account.

\subsubsection{IFRS 9 (Financial Instruments)}

\subsubsection{Measurement}

An entity shall recognize a financial asset or a financial liability in its statement of financial position, when it becomes party to the contractual provisions of the instrument. At initial recognition, an entity shall measure a financial asset or financial liability at its fair value, plus or minus or through profit or loss when not at fair value of the financial asset or financial liability or through transaction costs that are directly attributable to the acquisition or issue of the financial asset or financial liability.

When an entity uses settlement date accounting for an asset that is subsequently measured at amortized cost, the asset is recognized initially at its fair value on the trade date.

\subsubsection{Recognition}

An entity recognizes all its contractual rights and obligations under derivatives in its statement of financial position as assets and liabilities, respectively, except for derivatives that prevent a transfer of financial assets from being accounted as sale. If a transfer of a financial 
asset does not qualify for no recognition, the transferee does not recognize the transferred asset as its asset. The following are examples of applying the principle:

(a) Unconditional receivables and payables are recognized as assets or liabilities when the entity becomes a party to the contract and, as a consequence, has a legal right to receive or a legal obligation to pay cash.

(b) Assets to be acquired and liabilities to be incurred as a result of a firm commitment to purchase or sell goods or services are generally not recognized until at least one of the parties has performed under the agreement. For example, an entity that receives a firm order does not generally recognize an asset (and the entity that places the order does not recognize a liability) at the time of the commitment but, rather, delays recognition until the ordered goods or services have been shipped, delivered or rendered.

(c) Option contracts that are within the scope of this IFRS are recognized as assets or liabilities when the holder or writer becomes a party to the contract.

(d) Planned future transactions, no matter how likely, are not assets and liabilities because the entity has not become a party to a contract.

AS 13 requires investments to be categorized as follows:

(a) Current investments: are those readily realizable and intended to be held for less than one year, are carried at lower cost and fair value, with changes in fair value taken directly to profit or loss.

(b) Long-term investments: are those investments not classified as current, are carried at cost unless there is a permanent diminution in value, where a provision for diminution is required to be made by the entity.

For investments, Reserve Banking India regulations require similar classifications to IFRS, but the classification criteria and measurement requirements differ from those set out in IFRS.

Financial liabilities are usually carried at cost. There is no ability to designate instruments at fair value.

\subsection{International Accounting Standard 37 and Accounting Standard (AS) 29 (Provisions, Contingent Liabilities and Contingent Assets)}

Under Indian GAAP, provision for overlay has been accumulated on straight line basis while in IFRS the same is being built up in accordance with the provisions of IAS 37, Provisions, Contingent Liabilities and Contingent Assets.

The main difference is in recognition in IFRS Contingent Liabilities are to be included in Net Assets at fair value but in Indian GAAP Contingent liabilities are not recorded as Liabilities.

Under the International Financial Reporting Standards (IFRS) a provision is a liability, under IFRS it is described as Income Tax Payable. Similarly, warranty costs are treated as an expense under GAAP and a liability under IFRS.

The objective of AS 29 is to ensure that appropriate recognition criteria and measurement bases are applied to provisions and contingent liabilities and that sufficient information is disclosed in the notes to the financial statements to enable the users to understand their nature, timing and amount. Further, the Standard seeks to lay down appropriate accounting principles for contingent assets. Under AS 29, a provision should be recognised when:

- an enterprise has a present obligation as a result of a past event

- it is probable that an outflow of resources embodying economic benefits will be required to settle the obligation, and

- a reliable estimate can be made of the amount of the obligation.

IFRS defines provisions as liabilities of uncertain timing or amount. A provision should be recognized only when:

(a) an entity has a present obligation (legal or constructive) as a result of a past event.

(b) it is probable (i.e. more likely than not) that an outflow of resources embodying economic benefits will be required to settle the obligation, and 
(c) A reliable estimate can be made of the amount of the obligation.

The Standard notes, that, it is only in extremely rare cases a reliable estimate will not be possible. The amount recognized as a provision shall be the best estimate of the expenditure required to settle the present obligation at the end of the reporting period.

The best estimate of the expenditure required to settle the present obligation is the amount that an entity would rationally pay to settle the obligation at the end of the reporting period or to transfer it to a third party at that time. It will often be impossible or prohibitively expensive to settle or transfer an obligation at the end of the reporting period. However, the estimate of the amount that an entity would rationally pay to settle or transfer the obligation gives the best estimate of the expenditure required to settle the present obligation at the end of the reporting period.

The estimates of outcome and financial effect are determined by the judgment of the management of the entity, supplemented by experience of similar transactions and, in some cases, reports from independent experts. The evidence considered includes any additional evidence provided by events after the reporting period.

Provision is measured before tax, as the tax consequences of the provision, and changes in it, are dealt with under IAS 1.

\subsection{Accounting Standard (AS) 22 and IAS 12 (Deferred Tax)}

Under Indian GAAP, deferred tax liability has been recognized on timing difference while in IFRS, its been been recognized on temporary differences.

Accenting Standard (AS) 22 Taxes on Income advocates income statement approach. Under this approach, profit as per books is compared with profit as per tax. Then, deferred tax is created on all timing differences. Timing differences are the differences between taxable income and accounting income for a period that originate in one period and are capable of reversal in one or more subsequent periods. No deferred tax is created on permanent differences.

\subsubsection{IFRS}

A deferred tax asset is recognized if it is probable that sufficient taxable profit will be available against which the unused tax losses and tax credits can be utilized.

IFRS requires entities to account for taxation using the Balance Sheet liability approach which focuses on temporary difference between the carrying amount of an asset or liability in the statement of financial position and its tax base.

A deferred tax asset should be recognised for deductible temporary differences, unused tax losses and unused tax credits to the extent that it is probable that taxable profit will be available against which the deductible temporary differences can be utilised, unless the deferred tax asset arises from:

The initial recognition of an asset or liability other than in a business combination, at the time of the transaction, does not affect the accounting or the taxable profit.

Deferred tax assets for deductible temporary differences arising from investments in subsidiaries, associates, branches and joint ventures should be recognised to the extent that it is probable that the temporary difference will reverse in the foreseeable future and that taxable profit will be available against which the temporary difference will be utilised.

Deferred tax is to be created on revaluation of PPE and Intangible assets and the same is recognised in other comprehensive income.

Under IFRS, the cost of business combination is allocated to the identifiable assets and liability assumed by reference to fair values. However, if no equivalent adjustment is allowed for tax purpose, it would give rise to a temporary difference.

Temporary difference arise when the carrying amount of investments in subsidiaries, branches or 
associates or interests in joint ventures (namely the parent or investor's share of the net assets including carrying amount of goodwill) becomes different from the tax base (which is often cost) of the investment/ interest.

\subsubsection{Indian GAAP}

Deferred tax assets is recognised (a) if realisation is virtually certain for entities with tax losses carry forward, whereas (b) if realisation is reasonably certain for entities with no tax losses carry-forward.

Deferred tax is accounted for using the Income statement approach, which focuses on timing difference.

Deferred tax is not recognised as it is considered to be a permanent difference.

Under Indian GAAP, business combination (other than amalgamation) will not give rise to a deferred tax adjustment.

\subsection{IFRS 2 (Share-based Payment) vs. Indian GAAP}

The main reason in changing amount of Securities premium and General Reserves is due to difference in measurement in IFRS Employee share base payment shouldbeaccountedforusing fairvaluemethodbutaccording to Indian GAAP Employee share based payments are accounted either at intrinsic value or fair value.

Stock Option expense has been recognised with a corresponding entry to equity over the vesting period of the Option under IFRS 2, Share-based Payments. Stock Option Account relating to options exercised has been transferred to Securities Premium Account. Stock Option Account relating to options lapsed has been transferred to General Reserve.

\subsubsection{IFRS}

Recognised as an expense over the vesting period. Goods and services in a share-based payment transaction is recognised when goods are received or as services are rendered. A corresponding increase in equity is recognised if goods and services were received in an equity-settled share based payment transaction or a liabilities if these were acquired in a cashsettled share-based payment transaction.

\subsubsection{Indian GAAP}

There is no equivalent standard. However ICAI has issued a guidance note on Accounting for Employee Share-based Payments. This guidance note deals only with employee share-based payments. The SEBI has also issued the Securities and Exchange Board of India (Employee Stock Option Scheme and Employee Stock Purchase Scheme) Guidelines, 1999.

\section{Conclusion}

Many developing countries and countries with economies in transition strive to mobilize financial resources from domestic and international sources to attain their economic and social development goals. The availability of relevant information on potential investment targets has bearing efforts on mobilizing investment for financing economic and social development. Such information plays an important role in making critical investment decisions and conducting risk assessment. It also contributes to improved investor confidence and decreased cost of capital.

Over the years, attracting financing needed for economic development has become more competitive. Economic resources have become more mobile across borders. Enterprises that provide potential investors with reliable and comparable financial statements are more likely to attract domestic and international investment.

Noida Toll Bridge Company also tried to provide reliable and comparable financial statements based on both IFRS and Indian GAAP to attract domestic and international investment by considering Noida Toll Bridge Company financial statement we can absorb that there is different between IFRS and Indian GAAP so there exist difference in Intangible asset, Available for sale investments, Interest bearing loans and borrowings, Provisions, Deferred Tax Liability, Interest bearing loans and borrowings, Securities premium, Net unrealised 
gains on available for sale investment, General Reserves and Retained Earnings(profit \& Loss A/C).

\section{References}

Chua, W.F., \& Taylor, S. L. (2008). The rise and rise of IFRS: An examination of IFRS diffusion. Journal of Accounting and Public Policy, 27, 462-473.

Ramanna, K., \& Sletten, E. (2009). Why do countries adopt International Financial Reporting Standards? Working Paper \#09-102. Boston: Harvard Business School.

Sunder, S. (2009). IFRS and Accounting Consensus. Accounting Horizons, 23, 102.

\section{About the Author(s)}

Arash Naderian is a Research Scholar in the Department of Studies in Commerce, University of Mysore, India. Currently he is working in the area of financial performance of public systems.
Dr. B. Mahadevappa is a Professor in the Department of Studies in Commerce, Manasagangotri, University of Mysore, Mysore. He is the Deputy Co-ordinator of University Grants Commission's Special Assistance Programme in the department. He was a Post Doctoral Research Fellow of University Grants Commission, India. He has published thirty-two research papers in international and national referred journals and has presented thirty-six research papers in international and national conferences and seminars. He has successfully guided six doctoral students for their Ph.D. degrees and he is currently guiding eight doctoral students. He is the member of the International Society for Third Sector Research and International Society for Productivity and Quality Research, Indian Accounting Association, Indian Accounting Research Foundation and Quality Circle Forum of India. He can be contacted at: mahadevappa@commerce.uni.mysore.ac.in and bmahadevappa@gmail.com. 
